\title{
Solar cell and photonics outreach for middle school students and teachers
}

Pamela Gilchrist, Alonzo Alexander

Pamela O. Gilchrist, Alonzo B. Alexander, "Solar cell and photonics outreach for middle school students and teachers," Proc. SPIE 10452, 14th Conference on Education and Training in Optics and Photonics: ETOP 2017, 1045205 (16 August 2017); doi: 10.1117/12.2265782

SPIE Event: 14th Conference on Education and Training in Optics and Photonics, ETOP 2017, 2017, Hangzhou, China 


\title{
Solar Cell and Photonics Outreach for Middle School Students and Teachers
}

\author{
Pamela O. Gilchrist and Alonzo B. Alexander \\ The Science House, North Carolina State University, 909 Capability Drive, Raleigh NC USA \\ 27695
}

\begin{abstract}
This paper will describe the curriculum development process employed to develop a solar cell and photonics curriculum unit for students underrepresented in science, technology, engineering and mathematics fields. Information will explain how the curriculum unit was piloted with middle and high school teachers from public schools in North Carolina, high school students from underrepresented groups in an informal science program, and workshop settings. Measures used to develop the curriculum materials for middle school students will be presented along with program findings documenting students' urban versus rural interest in STEM, career aspirations, and $21^{\text {st }}$ century learning skills in informal learning settings.
\end{abstract}

Keywords: curriculum development, informal science program, solar cell, photonics energy system, green revolution, , teacher professional development, curriculum development,

\section{INTRODUCTION}

Energy literacy and sustainability play a significant role in the world and influence every aspect of life. Numerous studies show that energy-related knowledge in the United States is comparatively low ${ }^{1,2,3}$. Light and photonics are gaining their presence as key enabling technologies that are generally unfamiliar in the public sector. More work and resources are needed in schools and programs to develop students' awareness of energy and its impact in the world. Dewaters and Powers (2010) define energy literacy as a citizen's content knowledge, attitudes, and behaviors towards energy matters ${ }^{4}$. Millennial students are informed about energy initiatives, but are not motivated to address these problems through personal or collective actions ${ }^{5}$. One way to address the need of more knowledge, and shift values, beliefs, and attitudes is through engagement with modern energy curricula. Ramsey, Hungerford, and Zografakis found that problem-based challenges that integrate global, local, and social energy problems can shift students' values, beliefs, and attitudes ${ }^{6}$. Hence, the development of three Photonics Teaching and Research Modules on Fiber Optics, Light Emitting Diodes, and Solar Cells and Photonics by the Photonics Leaders II Project Team at The Science House, an outreach division within North Carolina State University. This purpose of this paper is to present the curriculum development process for the Solar Cell and Photonics Teaching Module, goals, modifications, dissemination methodology and descriptive findings of the curriculum dissemination with students and teachers through formal and informal formats.

The Solar Cell and Photonics Teaching and Research Module was developed to enhance high school students', (especially those historically underrepresented in physics and engineering) and teachers' knowledge, skills, and awareness of photonics, photovoltaic cells, the SMART grid, solid state lighting, engineering, and sustainable development principles. The module addressed science, technology, engineering, and math (STEM) principles that are often underutilized in a high and middle school teaching settings. The initiative promoted the interdisciplinary applications of light energy, solar cell technology, electronics, and engineering in an experimental, technical, and practical way. This significant collaborative endeavor introduced varying aspects of energy and innovative solutions to educators, students, and informal program providers. The goal of this collaboration was to further develop scientifically literate citizens to solve energy and sustainability problems, particularly within their own communities, workplaces, and in collegiate settings. Batterman, Martins, Antunes, 
Freire, and Gamerio emphasized the need to highlight the prominent role of energy in sustainable development, its presence in every sector, and our increasing dependence on both renewable and nonrenewable sources of energy ${ }^{7}$. Utilizing their framework, the Photonic Leaders II Solar Cell and Photonics Teaching and Research module served as a medium for educating students and teachers with relevant content resources and materials.

\section{SOLAR CELL AND PHOTONICS ACTIVITY MODULE DEVELOPMENT}

In August 2009, an advisory board of 10 professionals with expertise in physics research and education, electrical and computer engineer, technology, education, technology, biomedical engineering, programmatic design and evaluation outlined the scope of work for the module design. A graduate student with photonics content expertise was recommended by the advisory committee to develop the Solar Cell and Photonics module. The project staff and Advisory Committee also suggested that the module address knowledge and skill gaps found in college students entering physics and engineering programs. The curriculum design recommendations focused around experiments and problems that would develop students' scientific and engineering knowledge of photonics, technical skills, and communication and soft skills for the global workforce and college. The photonics graduate student worked closely with Project Staff and the Advisory Committee.

\subsection{Module Objectives and Skills}

The module was developed over a four-month window of time and reviewed by the Project Principal Investigators and Advisory Committee. Recommendations and input were submitted to the curriculum developer to test the curriculum with educators. The primary objectives of the module are as follows:

- Understand the operation of photovoltaic (solar) cells and light emitting diodes (LEDs), and dry cell battery source

- Identify electronic components, (i.e., resistors, alligator clips, LEDs, jumpers. Breadboards)

- Measure, analyze and interpret the power output of a solar and dry cell batteries

- Measure varying input conditions, (e.g., source wavelength, distance of source to solar cell, and source transmission through absorptive elements)

- Compare how solar and dry cell batteries power a light emitting diode (LED).

- Design, construct, and troubleshoot simple electronic circuits

- Extension project activities and experiments were provided to aid student application of knowledge and enhance learning about energy assessments, and installation of solar cells, including optimal angle of incidence and distance

- Develop an awareness of the 'green revolution' and how energy is harnessed and conserved

- Research and discuss cost, weight, implementation, lifetime, fragility and disposal of solar panels

The module was designed as an exploratory module that could be used as a: 1) stand-alone semi-structured inquiry unit where students are encouraged to work in teams to complete the activities through experimenting; 2 ) as a structured thematic unit whereby Science, Mathematics, Engineering Design, and Writing teachers could cover necessary content and skills needed to progress throughout the module; 3 ) a curriculum addition in the school and informal setting; or 4) an open-ended unit whereby students explore the solar cell technology, examine the characteristics, and use the extension suggestions to develop an independent research project. Dependent on student ability, the module could take five to twenty-five hours to complete if the extension activities are added as a research project or presentation assignment. For teachers, depending on their expertise, the module could be completed in 80 minutes or 240 minutes to provide facilitated instruction on materials, their role, and proper use of the various components in the curriculum module.

The Solar Cell and Photonics module engages participants in an exploration of solar cell and photonics content. The module begins with an introduction to the sun spectra, various light sources, photovoltaic cells, photons, direct current, batteries, LEDs, and the green revolution. The introduction is followed by guided investigations and just-in time instruction. Participants learn about solar cells, their various applications, and are asked to imagine additional applications of the solar cells. 
As stated in Section 1, the module goals were to further develop the STEM skills of the target audience and develop their potential for success in $21^{\text {st }}$ century workplaces and in collegiate degree programs. Participants are given different opportunities to learn new skills in topics where exposure would normally be minimal in the high and middle school setting. These topics include using a solar cell and a dry cell battery to power of a LED, comparing source wavelength outputs, comparing the spectra of the sun, experimenting with differing light sources, ,measuring solar cell and LED voltage, and examining optimal solar cell design data to determine the best design for solar cells installation. Below are several of the skills and objectives conveyed to participants throughout the module.

A. Employability and College-Preparatory Skills

- Ability to work in a team

- Ability to lead a team

- Written and verbal communication skills

- Problem-solving skills

- Strong work ethic

- Analytical/Quantitative skills

- Technical skills

- Creativity

- Initiative

- Detail-orientation - Maintain daily real-time laboratory notebooks

- Ability to follow laboratory rules and regulations

- Ability to work responsibly with minimal supervision

B. Technical and STEM skills

- Know characteristics of photons, solar cells, LEDS and dry cell batteries

- Identify measureable parameters to match the statement of work specifics

- Understand how to identify/design technical tasks for supervisory review

- Prepare technical documentation for assigned tasks

- Setup and design series and parallel circuits of varying complexity

- Measure and interpret characterization parameters of LEDs, Solar cells and Dry cell batteries

- Operate a digital multimeter

- Calculate resistance

- Troubleshoot and communicate systemic problems for given energy systems

- Read schematic diagrams

The skills and objectives of the Solar Cell and Photonics Teaching and Research Module align with the Partnership of $21^{\text {st }}$ Century Skills (P21) Initiative which emphasizes connecting the classical core content of the three Rs (reading, writing, and arithmetic) with the soft skills of the four Cs (communication, collaboration, critical thinking, and creativity). The overall goal is to equip ever student for the $21^{\text {st }}$ century. Prior to deployment with students and teachers, the project staff and Advisory Committee team reviewed the module content, exploratory approach and skill components to determine if the proposed curriculum was sound, aligned properly, and designed in a manner to provide learners autonomy during the experimentation process.

\section{SOLAR CELL AND PHOTONICS CURRICULUM PILOTING AND DISSEMINATION EFFORTS}

During the funding cycle of The National Science Foundation (NSF) Photonics Leaders II (PLII) Project, the staff and the curriculum developer designed the implementation and piloting schedule. An iterative process was employed to support ongoing modifications as needed to increase usability and applicability in schools and informal programs. The schedule indicated introducing the Solar Cell and Photonics Teaching and Research Module to middle and high school teacher participants of NSF PLII Blended Learning Photonics and Optics 
Teacher Professional Development to acquire immediate feedback and reactions from teachers regarding the utility of the resource, any constraints, and specific modifications. The NSF Information Technology Experiences for Students and Teachers Grant (\#833615) PLII project reached 4000 rural and urban students in public schools and 100 educators in Maryland, North Carolina, Rhode Island, South Carolina, and Virginia ${ }^{8}$ (NSF ITEST PL2 Final Report, 2011). The project provided access to curriculum materials, professional development and access to research expertise to use in their respective classroom or informal programs. Post funding dissemination of the module included a STEM Colloquium, national and state science conferences, and informal science programs. They also focused on the needs of educators in rural and urban areas, including curriculum modifications for public and charter schools to enhance students' and teachers' awareness, knowledge and behaviors towards energy-related curriculum.

The table below outlines the project pilot and dissemination efforts with the Photonics Teaching Modules

Table 1. Solar Cell and Photonics Curriculum Piloting Efforts

\begin{tabular}{|c|c|c|}
\hline Date & Pilot Efforts and Modifications & Modification/Suggestions/Findings \\
\hline Spring 2009* & $\begin{array}{l}\text { Piloted with } 20 \text { middle, high school and } 1 \\
\text { community college instructor }\end{array}$ & $\begin{array}{l}\text { Teachers requested more time to explore } \\
\text { the hands-on activities and access to } \\
\text { materials }\end{array}$ \\
\hline Summer $2009 *$ & $\begin{array}{l}\text { Implemented in the Photonics Leaders II } \\
\text { Summer program to } 40 \text { students }\end{array}$ & \\
\hline Fall 2009* & $\begin{array}{l}\text { Introduced } 40 \text { middle and high school teachers } \\
\text { at state science conference to }\end{array}$ & $\begin{array}{l}\text { Teachers were receptive of curriculum, } \\
\text { requested materials lists and supply } \\
\text { loans }\end{array}$ \\
\hline Spring $2010^{*}$ & $\begin{array}{l}\text { Introduced to } 15 \text { middle and high school } \\
\text { instructions at the national science teacher } \\
\text { conference }\end{array}$ & $\begin{array}{l}\text { Receptive embrace of the content from } \\
\text { high school teachers, some middle } \\
\text { school teachers were apprehensive with } \\
\text { creating circuits without step -by-step } \\
\text { instructions. Teachers preferred specific } \\
\text { procedures to assist learners with } \\
\text { exploring the content in a more } \\
\text { descriptive manner and limit some of } \\
\text { the exploration }\end{array}$ \\
\hline Spring $2010^{*}$ & 20 Middle and High School educators & $\begin{array}{l}\text { Teachers were receptive of the resources } \\
\text { and have continued to used the materials } \\
\text { provided }\end{array}$ \\
\hline Summer $2011^{*}$ & $\begin{array}{l}35 \text { Stem Program Coordinators and Directors at } \\
\text { a national STEM Conference }\end{array}$ & $\begin{array}{l}\text { Project PI and STEM Education } \\
\text { Graduate Student reorganized the } \\
\text { curriculum into five activities that } \\
\text { progressively layer more content and } \\
\text { disseminated the new format at the } \\
\text { STEM Colloquium - well received by } \\
\text { the participants }\end{array}$ \\
\hline Fall 2011* & $\begin{array}{l}\text { Introduced to } 70 \text { Native American Instructions } \\
\text { in a station format }\end{array}$ & $\begin{array}{l}\text { Mixed responses from educators. } \\
\text { Science and mathematics instructors } \\
\text { liked the format and requested another } \\
\text { session in their home county. }\end{array}$ \\
\hline Fall 2011* & Introduced to 45 Native American Instructors & $\begin{array}{l}\text { The Station format Solar Cell and } \\
\text { Photonics Curriculum activities to } \\
\text { introduce solar cell and photonics } \\
\text { content to instructors }\end{array}$ \\
\hline Spring $2011^{*}$ & 20 Middle and High School educators & PL2 Teacher Workshop \\
\hline Fall 2012 & 40 Middle and School Educators in Robeson & Additional introduction to \\
\hline
\end{tabular}




\section{County}

Summer $2016 \quad 50$ middle school students from urban and surrounding rural counties

Fall 2016

Spring 2017
10 teachers at the state science conference

26 middle school students from a rural county environmental safety with light and water and

Module implemented in informal science program was delivered in a thematic format with the solar cell and photonic module paired with supplementary activities that introduced insulators, conductors, how to create simple circuits, squishy dough circuit activity, solar water heater design and development, and solar cell and photonics curriculum exploration, with supporting mathematic activities that examine energy consumption, human power, and SMART Grid Simulation Curriculum delivered in open exploration format to middle, elementary, and high school teachers. Module implemented at a charter school using thematic format with the solar cell and photonic module paired with preparatory activities that introduce insulators, conductors, how to create simple circuits, squishy dough circuit activity, solar water heater design and development, and solar cell and photonics curriculum exploration, with supporting mathematic activities that examine energy consumption, human power, and SMART Grid Simulation

* Pilot/Dissemination activities during the project funding cycle.

\subsection{Solar Cell and Curriculum Module Modifications}

Modification suggestions from teachers resulted in the addition of supplemental content and the reorganization of the content into stations so that students or participants would experience the solar cell and photonics content through five interconnected activities. The stations outlined the materials needed and content covered in specific activity with semi-guided instructions. Images were added to enhance students' understanding of complex content and encourage exploration. Instructor input lead to the incorporation of LED breadboard activities with schematic diagrams and a 'resistor mathematics' inquiry activity to provide differentiation options within the Photonics Teaching and Research Module. The feedback from educators was incorporated into the draft module to improve the usability post-funding for dissemination at informal science programs and partnering schools. A STEM Education graduate student and the Principal Investigator modified the curriculum into the following five stations:

- Station 1: Calculating resistance

- Station 2: Powering a LED with a dry cell battery,

- Station 3: Powering a LED with a solar cell

- Station 4: Experimenting with a solar cell circuit

- Station 5: Wiring a simple LED circuit on a breadboard

- Extension Activities: Solar Cell and Photonics Activities (i.e., cost analysis, angle of light input, how wavelength of input light affects circuit conditions, series and parallel circuits impact on voltage and current in a circuit and an electronics and circuits activity) 


\subsection{Informal Science Dissemination with Middle School Students in Urban and Rural Settings}

The Photonics Teaching and Research Module was introduced to middle school students participating in Imhotep Academy, an informal outreach program created for student groups underrepresented in STEM careers in 1992. Imhotep Academy High Powered Energy session were offered to students from diverse economic, ethnic, academic, and geographic backgrounds in two phases, urban then rural, that occurred in June 2016 and March 2017, respectively. Each program engaged students in technical content, engineering design principles, and inquiry-based exploration of solar cell and photonics content and problem-solving techniques.

\subsection{Solar Cell and Photonics Informal Outreach Findings with Middle School Students in Urban and Rural Setting}

Figure 1. Comparison of school type for rural (Spring 2017) vs. urban (Summer 2016) students.

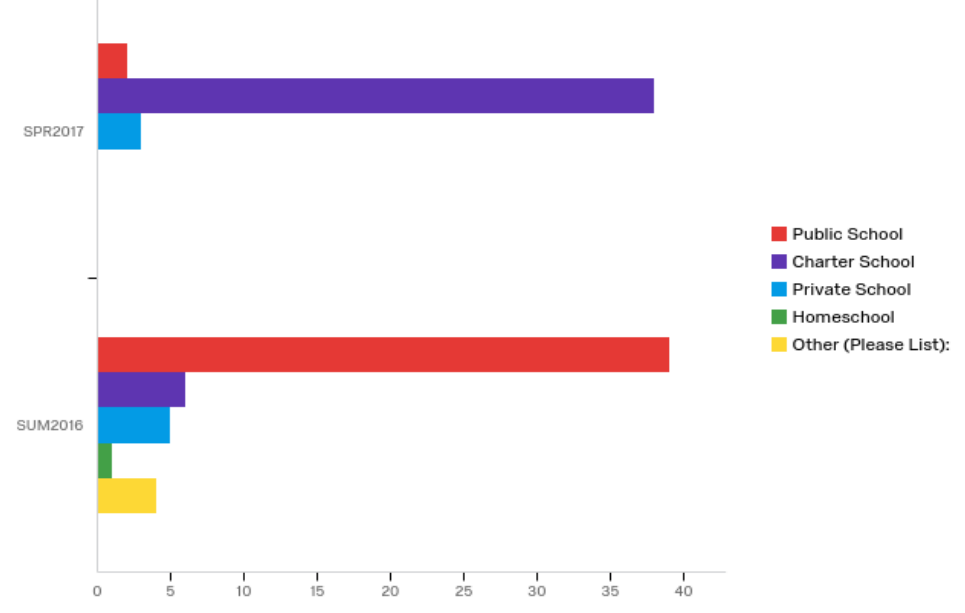

Students in both the urban and rural phases of the project completed two survey instruments intended to capture how their beliefs about STEM, and in particular their relationship to STEM learning and STEM careers, might have been impacted by participation in the Photonics Module. The results of these two survey instruments, the Student STEM (S-STEM) survey and the Burroughs Wellcome Fund Student Interest and Attitude Survey (BWF) are presented here. It is important to note the difference in school type for participants, as those who participated in the program in 2016 were mostly public school students and in 2017 were charter school participants.

The S-STEM contains three scales that measure separately student attitudes toward science, mathematics, and engineering and technology. They use a five-point Likert response scale $(1=$ strongly disagree to $5=$ strongly agree) and measure two sub-concepts of attitudes: self-efficacy and career interest. A fourth scale contains 11 items and measures student attitudes toward 21st century learning. Below are the Summer 2017 and Spring 2016 pre/post survey results. These results reveal high levels of student self-efficacy in both groups, increasing from pre-assessment to post-assessment without significant difference. 


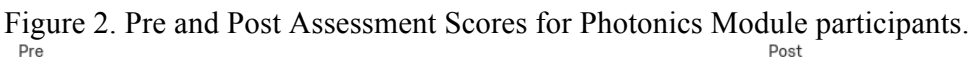
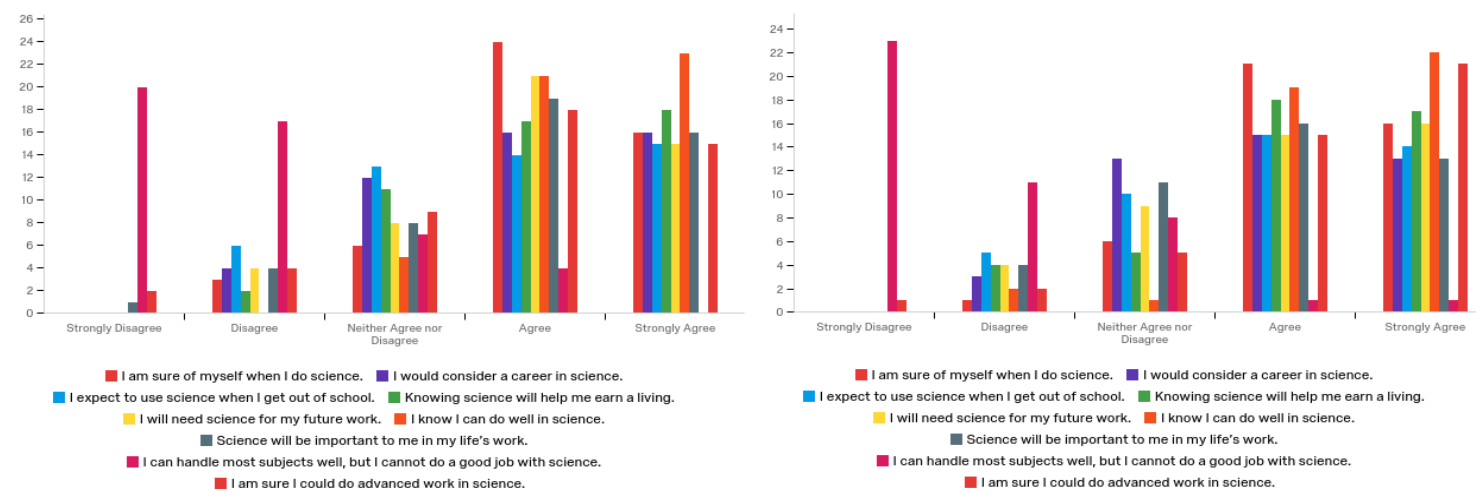

However, results for rural students were significantly higher compared to students who participated in urban areas on science attitude questions. This trend was also true in engineering attitudes. There was no significant difference in $21^{\text {st }}$ century skill attitudes.

An interesting result was difference in career interest levels presented by urban versus rural attitude scores. Rural students were significantly more likely to say they were interested in STEM careers, as shown in Figure 2. Urban participants are less likely to say that are interested in pursuing STEM careers as outlined in the SSTEM instrument. This response may indicate saturation in science content for urban students compared to rural students, giving them a better idea of what a career in STEM might look like. This would help them know whether they would like a career in STEM, but also whether they would not enjoy a STEM career.

Figure 3. Levels of interest in STEM careers for urban and rural students. Clustering to the right indicates high interest.

SUM2016

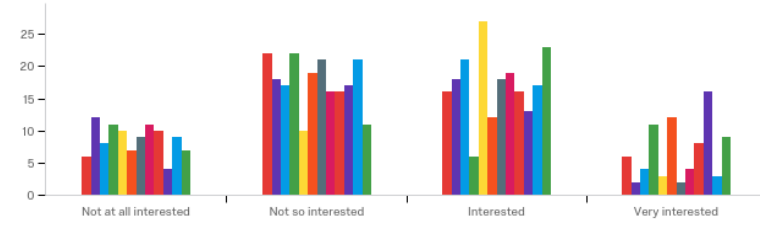

SPR2017

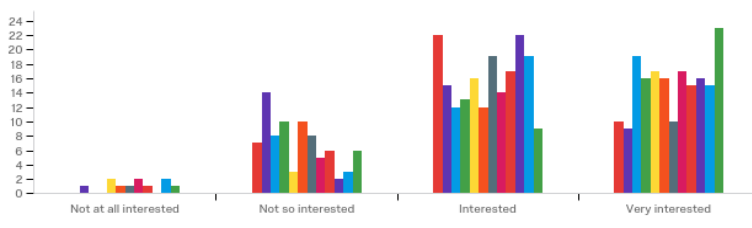

Figure 4. Science attitude scores for rural (Spring 2017) vs. urban (Summer 2016) students. Clustering to the right generally indicates higher levels of self-efficacy. Note that data in magenta are negatively coded.

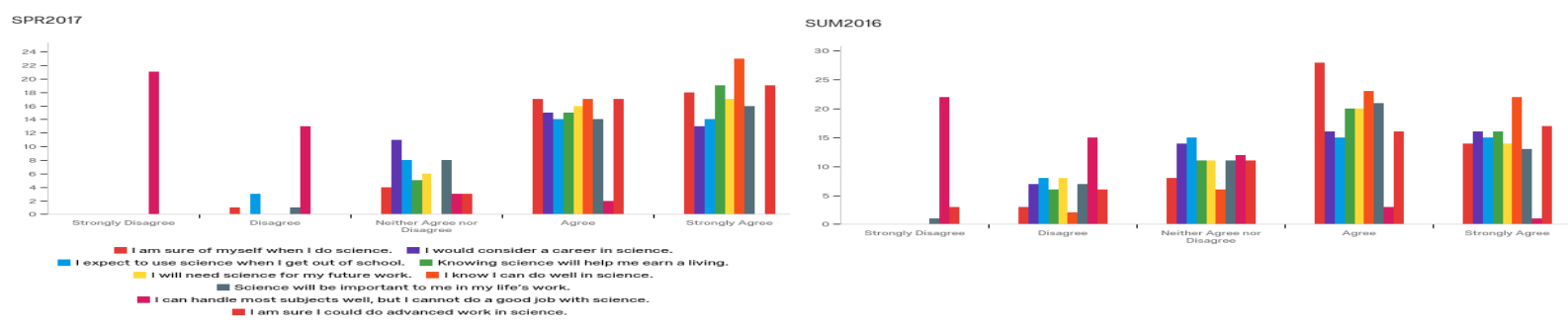


Table 2. BWF Survey Responses for urban and rural phases.

\begin{tabular}{|c|c|c|c|c|c|c|c|c|c|c|c|c|c|}
\hline \# & Question & Strongly & isagree & $\begin{array}{r}\text { Some } \\
\text { disa }\end{array}$ & & $\begin{array}{r}\text { Neither a } \\
\text { disa }\end{array}$ & ree nor & Somewl & $t$ agree & Strongl & agree & $\overline{\text { To }}$ & \\
\hline & & Summer & Spring & Summer & Spring & Summer & Spring & Summer & Spring & Summer & Spring & Summer & Spring \\
\hline 1 & $\begin{array}{l}\text { This program } \\
\text { helped me } \\
\text { understand } \\
\text { science better. }\end{array}$ & 0 & 0 & 2 & 1 & 13 & 2 & 22 & 14 & 2 & 8 & 39 & 25 \\
\hline 2 & $\begin{array}{l}\text { Because of } \\
\text { this program, I } \\
\text { feel better } \\
\text { about being } \\
\text { able to learn } \\
\text { science. }\end{array}$ & 1 & 1 & 1 & 1 & 16 & 3 & 16 & 10 & 5 & 10 & 39 & 25 \\
\hline 3 & $\begin{array}{l}\text { I learned some } \\
\text { things in this } \\
\text { program that I } \\
\text { can use in } \\
\text { science class } \\
\text { at school. }\end{array}$ & 0 & 0 & 7 & 1 & 7 & 2 & 14 & 17 & 11 & 5 & 39 & 25 \\
\hline 4 & $\begin{array}{l}\text { Because of } \\
\text { this program, I } \\
\text { think I am } \\
\text { more aware of } \\
\text { the importance } \\
\text { of science in } \\
\text { everyday } \\
\text { living. }\end{array}$ & 0 & 0 & 2 & 1 & 9 & 6 & 17 & 11 & 11 & 7 & 39 & 25 \\
\hline 5 & $\begin{array}{l}\text { I tell my } \\
\text { family or } \\
\text { friends about } \\
\text { the things we } \\
\text { do in this } \\
\text { program. }\end{array}$ & 2 & 0 & 5 & 2 & 3 & 6 & 7 & 8 & 22 & 9 & 39 & 25 \\
\hline 6 & $\begin{array}{l}\text { Because of } \\
\text { this program, I } \\
\text { am more } \\
\text { excited about } \\
\text { science. }\end{array}$ & 1 & 2 & 5 & 0 & 16 & 4 & 11 & 9 & 6 & 10 & 39 & 25 \\
\hline 7 & $\begin{array}{l}\text { Because of } \\
\text { this program, I } \\
\text { think I have a } \\
\text { better } \\
\text { understanding } \\
\text { of what } \\
\text { scientists do. }\end{array}$ & 1 & 1 & 3 & 1 & 10 & 2 & 17 & 11 & 8 & 9 & 39 & 25 \\
\hline
\end{tabular}


Figure 5. Graph of BWF Survey results for questions 1-7.
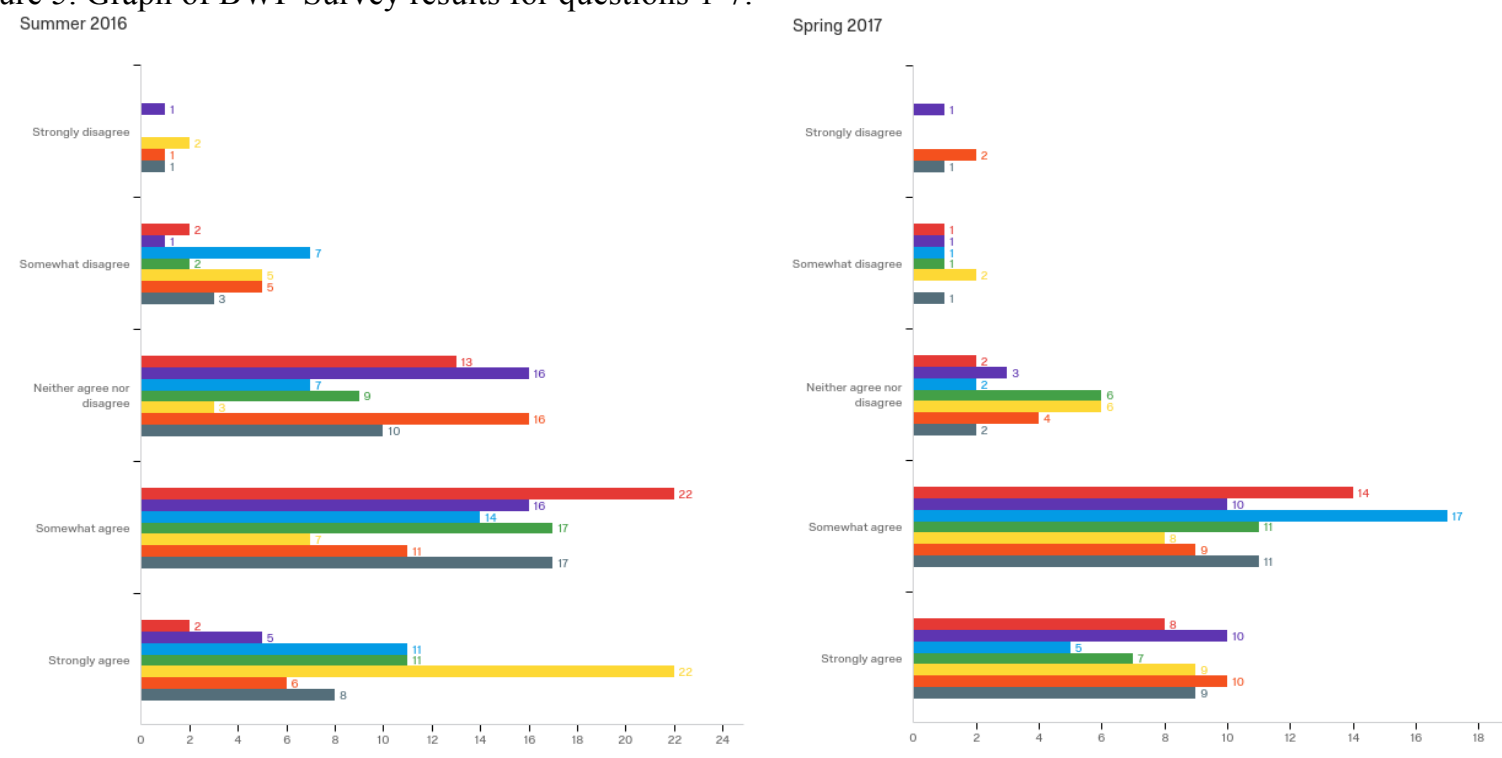

The BWF survey is only administered as a post-participation instrument. Therefore, the interesting results for the BWF instrument look at differences between the two program phases. For the BWF results, questions (1) and (2) were significantly different at the 0.05 level in an unpaired two-way t-test.

Table 3. Chi Square results for statistically significant BWF survey questions.

\begin{tabular}{c|c|c}
\hline & & \\
\hline & Chi Square & Summer 2016 vs. Spring 2017 \\
1. This program helped me & Degrees of Freedom & 28.51 \\
\cline { 2 - 3 } understand science better. & p-value & 16 \\
& & 0.03 \\
2. Because of this program, I feel & Chi Square & 26.13 \\
better about being able to learn & Degrees of Freedom & 16 \\
science. & p-value & 0.05 \\
\hline
\end{tabular}


As noted on the S-STEM instrument, students in urban and rural setting were significantly different in related to questions of self-efficacy in science. This may be a result of the lack of exposure to problem-based science content in rural settings, therefore leading to a sense of false confidence in their abilities as scientists. On the other hand, urban students repeated exposure might mitigate any increase in science self-efficacy because students already feel capable as scientists. Further qualitative study of this issue is needed to understand these urban versus rural differences.

\subsection{CONCLUSIONS - NEXT STEP}

Photonics and Solar cell technologies infuse every sector of society. Research occurring in these fields are often unknown to students and educators. Informal science outreach programs play an important role in introducing technical content to students and educators, partnering with researchers in the field to disseminate content to broader audiences, and contributing feedback in the development process. Additionally, further understanding of student attitude results is necessary to clarify whether repeated participation in STEM outreach is useful for encouraging students to pursue STEM careers.

\section{References}

${ }^{1}$ Barrow, L.H., Morrisey, J.T., 1989. Energy literacy of ninth-grade students: a comparison between Maine and New Brunswick. Journal of Environmental Education 20, 22-25.

${ }^{2}$ NEETF, (2002). Americans' low “Energy IQ”: A Risk to Our Energy Future/Why America Needs a Refresher Course on Energy. National Environmental Education \& Training Foundation, Washington, DC.

${ }^{3}$ Curry, T.E., Ansolabehere, S., Herzon, H., (2007). A survey of public attitudes towards climate change and climate change mitigation technologies in the United States: analyses of 2006 results. MIT LFEE 2007-01 WP.

/http://sequestration.mit.edu/pdf/LFEE_2007_01_WP.pdfS (accessed 2009).

${ }^{4}$ DeWaters, J. E., \& Powers, S. E. (2011). Energy literacy of secondary students in New York State (USA): A measure of knowledge, affect, and behavior. Energy Policy, 39(3), 1699-1710. DOI: 10.1016/j.enpol.2010.12.049

${ }^{5}$ Twenge, J. M., Campbell, W.K., Freeman, E.C. (2012). Generational Differences in Young Adults' Life Goals, Concern for Others, and Civic Orientation, Journal of Personality and Social Psychology, 1966-2009 Vol 102-5 pp1045 -1062 DOI: 10.1037/a0027408

${ }^{6}$ Ramsey, J.M., Hungerford, H.R., (1989). The effects of issue investigation and action training on environmental behavior in seventh grade students. Journal of Environmental Education, 20, 29-34.

${ }^{7}$ Batterman, S.A., Martins, A. G., Antunes, C. H., Freire, F., and M. Gamerio de Silva, (2011), Development and application of graduate programs in energy and sustainability, Journal of Professional Issues in Engineering Education and Practice, October 2011, $198-207$.

${ }^{8}$ Gilchrist, P.O., \& Bowles, T. (2011). National Science Foundation Information Technology Experiences Final Annual Report Photonics Leaders II 